\title{
レーザー関連学会報告
}

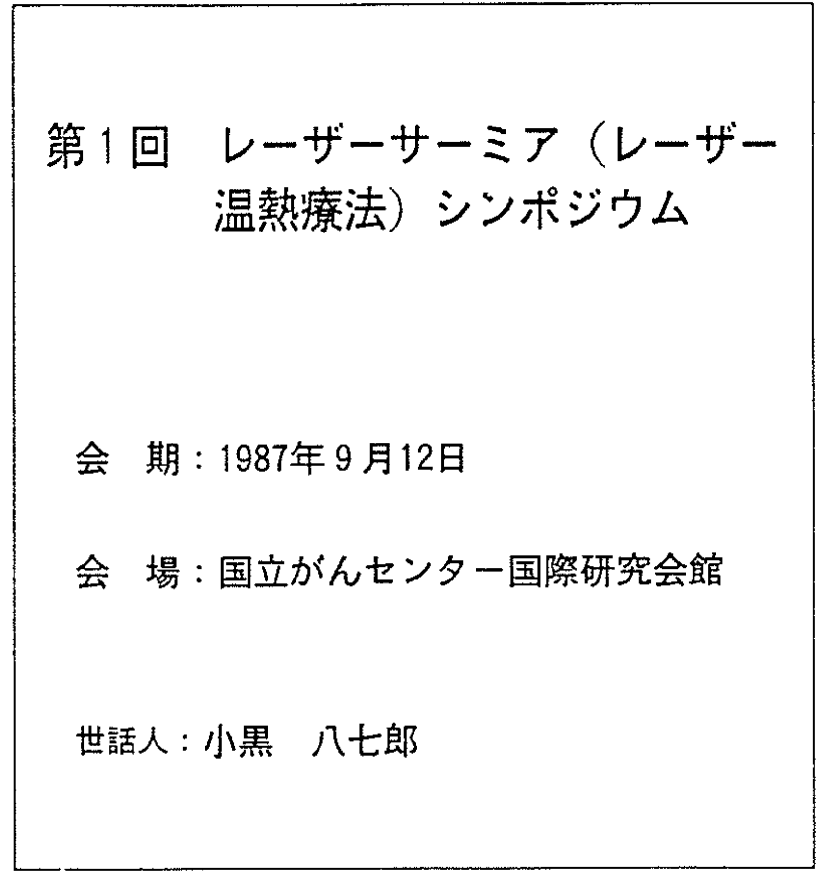

〈プログラム〉

シンポジウム1 座長：大山 勝

1. 安䔖, 2, 昇, 3 , 水城

シンポジウム2 㭫長: 福富 久之

4. 鈴木, 5。恒川。 6 。松島

シンポジウム 3 座長: 菊池 眞

7. 木附, 8。藤鼻

特別满演 坐長：小黒八七郎

柄川 順：温熱療法の基礎亡笑際

招待講演 Stephen M.Waldow(Wenske Laser Center,

Chicago):

Hyperthermia Potentiation of Photodynamic Therapy Employing

Photophyrin and : Comparison of Results Using Three Animal Tumor Models
〈抄録〉

シンポジゥム $1-1$

1. 眼憸悪性腫瘍のレーザーサーミア による治療

安藤 文隆

国立名古屋病院眼科

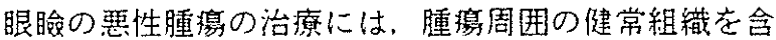
屯広範な切除が必要であり，眼瞼の欠損部に対しては 璉々の眼睑再建術が工夫さ扎ている。しかし，睡湯切除 による欠損部が大きな場合には，再建術が困難であるば かりでなく、術後に醜形や機能障害を残して，患者を苦 しめるこよも少なくない。眼瞼要性腫瘦切除によるこれ らの欠点を回避するため，連続発振型Nd:YAGレー ザー茎用いたレーザーサーミアを1例の眼瞼墨性腫浧に 試み、その経過を1年4カ月にわたって観察した。

症 例

症例は82歳の女性で、初診は1986年3月20日である。

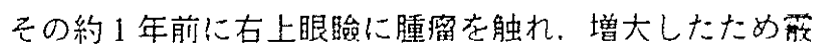
粒腫よして近医にて切開手術を受けた。しかし，その後 2 回再発、再切除を繰り返したため組織娭查を行い，マ イボーム氏腺癌と診断され，腫瘍広蘴切除の目的で国立 名古屋病院腿科入紹介さ机て来た。初診時. 右上眼跲上 から腫留在触れ，上眼瞼を反転すると睑結膜上から巨大 乳頭状に增殖した腫㿉組織塊を認めた。しかし，耳前腺 等は触机ず、腫痽の移転在思打せる所見は認めら机な かった。

治療法㧍よび経過

マイボーム氏腺㾚は極的瑟性度が高く，一般に健常 眼球を含む眼禽内容除去街が適応である。しかしこの患 者は下半身麻慎があって歩行困難であり，さらに高歯を 理由に広範な上眼睃切除等の観血的治癔を欲しなかった たわ，局所温熱療法を試みた。

腫㾴組擮の加温には人エサファイア製局所温熱用プ ローブを用い，連続発振型Nd:YAGレーザー装圈に接 続して行った。べノキシール囚点眼麻酔後上眼睃を反転 し、結膜側から腫湯瑰に向けて局所温熱用プローブを押 しなて、局所温度をコンピューター制樾しつつ. 2 ワ 
トの低出力断続照射で42〜 $45^{\circ} \mathrm{Cに}$ 維持した。そして1 クール15分間の加温を2週間隔で前後 3 回行つた。腫疼 が篗小した第 2、第3クールの照射時には，熱感老强く 訴えるようになったため，2％キシロカインによる局所 麻衉下に加温した。

第 1 回照射 2 週間後頃上り腫瘍は著明に縮少しはじめ， 3 回の治療劣終えた 5 週後には，眼瞼上から腫㨨在全く 触知しなくなっていだ。しかし，その約 2 力月後の1986 年 8 月 7 日の来院時に, 上眼瞼皮席面加皮符上瘾着し ていない限局性小腫留を触知できたため。20分間の局所 温熱癔法を追加した。この追加治療にて小腫瘤は一時維 少したが、11月上旬再び小腫留を触㧈、徐々に增大して 来ている。そして1987年8月末現在, 皮下組織と痖着し ない小指頭大の小腫留に增大しているが，結膜面には充 血等の異常も認めていない。また現在まで耳前腺は触れ ず、癌腫の移転を思わせる所見は認めていない。

このYAGレーザーを用いたレーザーサーミアは，眼 瞼悪性腫楊を完治には至りしめ得なかったものの著明に 缩少させることはできた。

他のエネルギー源による温熱療法と同じく、放射線癔 法との組台せにより完治に導き得万可能性とは別に、非 観血的療法由に転移の后険性が少ないことを期待して。 レーザーサーミアを繰り返しつつ，経過観察できる可能 性を追求したい。

\section{シンポジウム1- 2}

2. 頭頸部癌に対するレーザーサー ミアの基礎的, 臨床的検討

昇 卓夫, 森山一郎, 大山 勝 鹿児島大学医学部耳鼻咽喉科学教宣

癌の集学的治療法の一つとして注目されている局所 hyperthermiaは、いず扎もアプリケータや電極板等. 加温装置の都合上. 頭頸部領域には応用し難い点が多い。 これは頭頸部領域が搆造的に四凸が著しく，複雑な骨。 軟部組祴構筑を示しているためでする。

我々は，接触照射が可能となったNd-YAG laserを 利用し. laserの組鐡内刺入に上るhyperthermia. す なわ方“laserthermia”在用いて、頭钼部癌の研究，治 療在行っている。Nd-YAG laser先端に，全方位照射 可能な特殊な ceramics probeを装着することにより。 一点集光型のメスとして用いるのではなくて，三次元的. 局在性の熱作用老利用する一理の局所 hyperthermiaて ある。正常家鬼、舌への影響を見てみる上，辺緑温度41.5 ${ }^{\circ} \mathrm{C}-43^{\circ} \mathrm{C}$ ，30分間の加温を行った加温苜後３日目の病 理組織学的变化は軽微であった。また，生化学的にも同 部位の組織について，炎症性变化の一指標としてアラキ ドン酸代謝産物の唡索を. 5-,12-,15HETE，PGE 2 について、直後３日後８日後に行った。8日後にははぼ 正常に復し. laserthermiaに上る正常周国組織への影

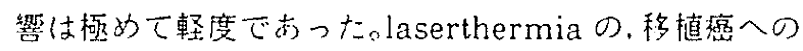
影響在見るべく、ヒト甲状腺の anaplastic carcinoma 芯移植した20匹のヌードマウスの腫留に対して. laserthermia 在行った。腫瘤の移植部位は背部皮下とし、移

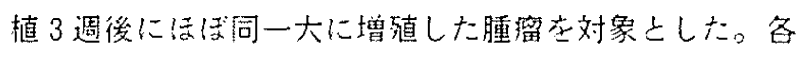
5 匹ずつのヌードマウスの4 群.すなうち laserthermia 単独群，シスプラチン単独療法群, laserthermiaとシ スプラチン併用群.control 群について娭索した。 laser の出力は $1 \mathrm{~W} と し$. ceramics probe から約 $5 \mathrm{~mm}$ 離れた 所の局所温度在加温の目安として。温度計在刺入測定し た。ネンブタール麻酔下に局所温度が $43^{\circ} \mathrm{Cになるまで}$ レーザー照射を行い，その娞20分間，同温度の䒬囲で， 照射を断続的に繰返した。laserthermiaは1回のみ行 い、シスプラチンの投与は、レーザー照射の前日に2.4 $\mathrm{mg} / \mathrm{kg}$ 壳. one shot で腹腔内に投与した。肉眼的な腫 瘍の大きさを1週每に3週間測定し、レーザーサーミア +シスプラチンの併用群で，最大の睡痬縮小効果志認め。 睡譺の成長はほとんど怨めら机なかた。次いでシスプ ラチン单独群。レーザーサーミア単独群の䐓で勃果が認 やられた。

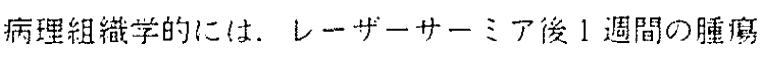

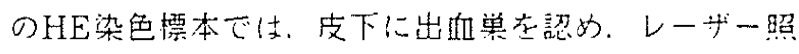
射の及んている所の䄄胞(大,ルーズになり遊離傾问在示 していた。䒠た核の消失や膨化がすり，細胞变性が認向 ら机た。レーザーサーミア在行う際の血流の变化を、電 気分解式水素クリアランス法血流計で見ると、腫溲内の 血流は，probe 近くでは，照射後上り城少しはじあ。 レーザーサーミア中は，血流の減少去示し，20分間の レーザーサーミア後も縓やかな賋流回復しか認めなかっ ホ。こ机に対し、中心部上り蜼机た腫激の辺緑部では。 
照射開始時より徐々に増大し、レーザーサーミア終了時 まで增加傾宁が糸められた。

䛗床的には，頍頸部腫揚20例に対し、レーザーサーミ

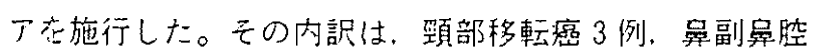
要性腫瘍 4 例，甲状腺癌 2 例，舌口腔咽頭癌 10 例，扁挑 癌つ上咽頭櫵屡例 1 例である。 laser出力は1-3Wで. $43^{\circ} \mathrm{C} ， 1$ 回照射時間を30分とし、1 週間に1回行った。 1 例を除く19例に対して，放射線療法や化学痖法を併用 し、 5 例がCR，11例にPRの結果が得ら机た。接触型 レーザーを用いるレーザーサーミアの場台, 多少の侵態 は避けがたい方法ではするが，当科領域のように，腫㾤 を明視できる領域では，むしろ，刺入が確実で，効果判 定も容易である。特に，放射缐感受性の低い，化学療法 の唂果の薄いとさ机る腫瘍での，そ机らの增感効果を 组った使い方は，臨床的にも有望で，その効果が大いに 期待さ机るところである。

\section{シンボジウム $1-3$}

3. 口腔癌治潦におけるレーザー サーミアの適応

水城 晴美, 清水 正嗣，柳澤 繁孝 大分医科大学歯科口腔外科

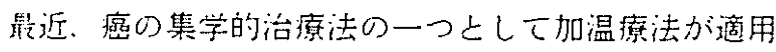
されりつする。局所加温療法には、同所潅流、マイクロ 波、RF波などに上る加温方法があるが、搆成組織が多 様で形態的にも複雑な口㬳領域に方いてはレーザーに上 るレーザーサーミアが今後広く適応さ机る上思机る。

非科では最近レーザーサーミアを試みる機会圭えたの で、きの経騒の䀧要を報告した。

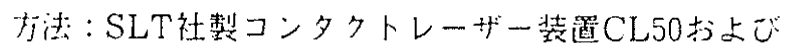
コンピューター制御レーザーサーモシステム在用いてお こだた日

本装置のシステムは、レーザー采。制御・温度モ二 ター系方上じコンピューター系の3 回路亦的構成さ㣗て 拉り，組識内温度制御の方法は、温度センサーで測定さ れる組裁内温度が。設定さ扎た上限コントロール值に達
するまでレーザーで加温，その後レーザー照射を中断し． 下限コントロールまで下降すると再び加温するという， ON, OFFをコンピュータで制衙しながら繰り返すこと によってなさ机る。

加温条件は，レーザーの有効出力を 5 W 前徭, 照射 モードをパルス波に、ON, OFF時間を各0.5秒，上眼コ ントロール温度を $44^{\circ} \mathrm{C}$, 下限コントロール温度を $43^{\circ} \mathrm{Cに}$ 設定して行った。

用いたプローブは長さ $15 \mathrm{~mm}$ の接触型高拉散マイクロ ロッドで，ハンドピース付萛腔用あるいはロ然用レー ザーファイバーの先端に装着して使用した。プローブは ほぼ全長を組織内に刺入し、金属整温度センサーはプ ローブの刺入長の約 $1 / 2$ の長さまで刺入し、センサー とプローブとの距離は3〜10 m種々の条件で試みた。

症例：症例 1 は66歳の男性で, 約 1 年前に当科を受診 し. 口底部屚平上皮癌 ( T $4 \mathrm{~N} 1 \mathrm{MX})$ と診断さ机た症例 である。初回治療はX線30Gy 外照射，頸部郭清，下顎 およびロ底舌半側切除. CDDP + BLMによる化療を計 3 回行ったが、その娞銷骨上部拉よび胸部の転移栄が增 大したため、CDDP + BLM黁法在 2 回甫上び鎖骨上部 にレーザーサーミアを計 3 回施行した。化療による腫瘄 の著明な箯小はみら机なかったが、レーザーサーミアを 行った部位は直径15mmの大きさで周国上りも明らかに諙 凹范呈していた。

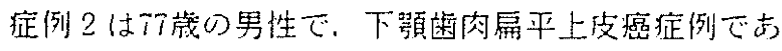
る。BLN投与, X線58Cy 外照射に上る初回治療》䄪 1 年㣪に，舌に腫瘍の再発を認妨た。患者は心，堅疾患を

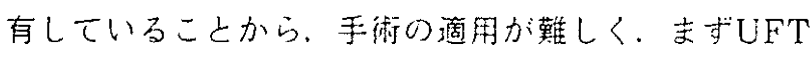
の内服とレーザーサーミアを試みた。症例1に比ベて， 上限温度がやや高くなり。プローブ刺入部位周围の力ー ボン形成が多い上うに思扔机，また畽痬は徐々に增大し。 レーザーサーミアによる明的な治療効果は認めら机な ふつた。

以上，わ扎わ机心経験は去だわずか2例にすぎないが， 施行部应、組織に上って温度分布、伝達範用。佉達速度 が、またプローブ，温度センサー間距嚾に上って加温温 度が異なっていた。

またレーザーサーミアは加温筥用が娦いが，腫楊を直 接扣温できるという利点がすり， 口腔領域には有用な方 法と思わ机た。 
シンポジウム $2-4$

4. 消化器内視鏡における レーザーサーミアの検討

鈴木 荘太郎, 青木 純, 三輪 剛 東海大学内科 6

\section{I 、はじめに}

筆者らは1979年YAG laser 尊入当初より laser 照射 による消化管粘膜に及ぼす影響を組織学的に梌索し臨床 饦用の女安性を検討した。さらに照射に及ぼす胃粘膜組 織血流による影響を椮討し、照射条件を設定した"”。198 3年より石英Fiber による非接触照射の不確実性よ Fiber の破損を改善した ceramic 製接触端子 contact

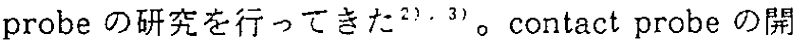
発により20〜30W以下の低出力接触照射で効果が得られ， probe 先端形状を変えて. 光凝固. 蒸散のみならず切開， 止血，局所温熱治療が可能となっだ1゙。

II. 接触法による laserthermia の開発

1。組織局所温度制御方式の開発

円錐型の高拡散 probe を組織に刺入し, probe を中 心とした球形の範囲に laser 光および熱エネルギーを拡 散させることができる。 2 channel fiberscope を用い probeと温度センサーを一定間隔で粘膜面に刺入し，組 織温度測定しながら 3 W以下の低出力照射により局所 温熱効果が得られた。さらに手動式温度制御方式では精 度に限界があり computer control system 絫開した。

2 . 組織学的検討

1) 光凝固による効果

雑喠成犬の罢壁において, flat probe（円柱型）10W， 1.0秒照射で阽膜層のみの变化であったが４．0秒照射に より粘膜下層を貫き， $45 \mathrm{~W}, 1.0$ 秒照射之同等の効果を 示した。即ち接触法によって laser 光の損失が隇少し， 非接触法より照射勃果が客観的に jouleで此較しうる。 一方, 照射効果の深達性が增し 40 W以上の出力. 4.0 秒 以上の連続照射によって胃壁を貫く凝固变性をきたし危 険である。

2) laserthermiaによる効果

出力3. OW. 0.5秒 pulse で computer control 照射時
に probe 上温度センサーの間隔が $6.0 \mathrm{~mm}$ の場台に直径 12 㥸の範囲で $42.0 \pm 1.0^{\circ} \mathrm{C}$ に組織温度が維持され laserthermiaの適切な条件と考えた。組織学的には温度が 上昇した範囲で粘膜層の浮腫，うっ血，粘膜下層の血栓 形成をみとめ，中心部は浅い潰婸を形成したが，1２

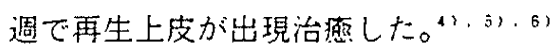

実験腫瘦 (ENNG 発癌ビーグル犬)に対する laserthermiaにより腫癔は肉眼的に消失したが，組織学的に は腫境細胞は残在していた。1986年より併用療法として 手術非適応胃癌例に対し laserthermia の応用を開始し， 肉眼的に腫瘍縮小効果を認めた。

III.まとめ

筆者らの開発した computer control system 上一体 化した低出力YAG laser 装置が商品化され，女定した 接触照射治療が可能となった。現在，laserthermiaにお いて、より安定した 1 channel 方式 feedback sleeveの 開発を行っている。今後、消化管癌に対する laserthermia の効果に関して、組織化学を主とした綿密な㛟討が必要 之考える。

\section{文献}

1) 鈴木荘太郎, 他：消化器内視鏡に抢ける $\mathrm{Nd}: \mathrm{YAG}$ レーザーの基礎的検討および臨床応用. Prog. Digest. Endosc.. 20:21, 1982.

2) 鈴木荘太郎。他：消化管粘膜に及ぼすレーザー照射 の影響（第 6 報）一接触型レーザーロッドによる基毞 的研究. Gastroenterol. Endosc. , 26 : 705. 1984.

3 ) S.Suzuki, et al. : New ceramic endoprobes for endoscopic contact irradiation with Nd:YAG las er : experimental studies and clinical applications. Gastrointest. Endosc., $32: 282,1986$.

4) 铪木荘太郎，他：内視鏡下Nd:YAGレーザー温熱 療法に関する基整的研究および制御システムの開発. 日本レーザ一医学会誌。6：347。1986.

5 ) 鈴木荘太郎，他：レーザーを用いたハイイ゚ーサーミ アの試みNd:YAGレーザーによる内視鏡的局所温熱 療法, 消化器化，4：363. 1986.

6) 铪木荘太郎, 他：接触型愁光端子 endoprobeに上 るNd:YAGレーザー内視鏡治療の唡討. prog. Digest. Endosc.. $29: 32.1986$. 


$$
\text { シンポジウム } 2 \text { - } 5
$$

5.レーザーサーミアに関する 基礎的, 臨床的検討

$$
\text { 恒川洋 }
$$

名鉄病院消化器科

我々は共同研究皆の大工園 (SLT-Japan)の協力の もとに。1984年に、Nd:YAGレーザーの低出力照射に 上る局所㾇温熱療法（レーザーサーミア）壳開発した。 以来，本療法の腄韵破壊の機序を解明するため。種々の 基䃈的娭討花行ってきた。アウス移植腫瘍在用いた，高 出力短時間照射 (Tip 型接触照射) と低出力長時間照射 (レーザーサーミア)上の比較実験では照射直㣪の超音 波像、病理組織像に明らかな䔔いを認めた。すなわち。 高出力短時間照射では照射直後から，照射部に凝固．填 死が生じたのに対し，低出力長時間照射では照射值後の

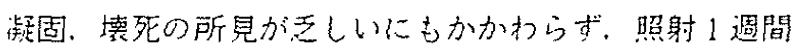
徭には高出力单時間照射之同样の広範な凝固壊死層学認 めた。志た、レーザーサーミア施行中，コンピュー夕ー に上り $43-44^{\circ} \mathrm{C}$ に制御。維持された湶巣部の組織学的变 化は照射直後では之しく、3 時間後から明䁖よなった。 こ机的の铅果は，本療法後の㦄の变性，壊死にいたる過 程か高出力短時間照射とは異なること在示滧している。 次に腫湟内温度が $43-44^{\circ} \mathrm{C}$ に維持さ机た部位のみならず,

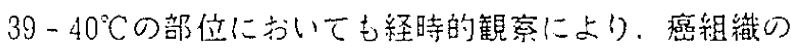

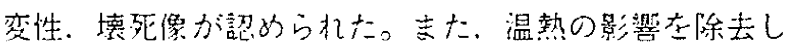
た状態でのラット揞等肝細胞在用いた invitroの実騒 成績より。レーザー光自身にも。なんらか心䄄胞障害作 用があることが明らかよなった。こ的ははレザーによ 石温熱勃果に加元、レーザー光自身が癌の破填，消失に 関与している可能性去示惨するもので方る。基礎実騒の 結黑をもに，喠々の臨床応用を行った。疾患領域は消

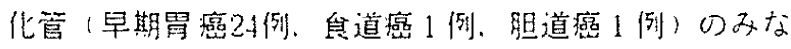

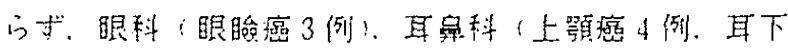

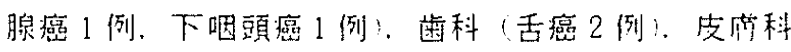
（皮席虎1例：上多岐にわたつている。癌病变全体の治 療目的達成率は81.6. 次に，早期罱癌2 4 例，街前照射群20例，局所根治目的群
4例)を対象に臨床的娭討を行った。陷凹型早期置癌20 例に対して、1 から3 回の試験照射徯，1週間以内に切 除された盟を用いて癌の残存の有無を組織学的に㛟討し た。その結果４例で癌病窲の完全消失を確認した。次 に. 癌の連残をレーザー溃瘲の辺縁上底部に分けて娭討 すると，癁の遠残がレーザ一溃瘾の辺縁のみにみられ底 部にはみられなかったものが13例，辺縁と底部の両方に 認められたものがる例であった。すなわち，街前試験照 射20例中，17例，85\%ではレーザーサーミア後の潰償の 底部に麽病棵の遭残はなかったことになり、レーザー サーミアの照壁深部への照射勃果力゙示唆された。次に， レーザーサーミア後の罥壁の変化の特徽は，照射部の炶 膜下盘から固有筋層上部の癌組識が变性，壊死に陷って いるにもかかわらず，胃壁表尿の变化はびらんももしく は浅い溃舅（UI-II）のみであり，深い潰瘦(UI-III. IV)の形成は僅かであった。こ机はレーザーサーミアが 陷凹型癌に対する効果的かつ安全な照即方法之なりうる ことを示す結果である。声た，癌の消失に必要な照射時 間，照射量の娭棓結果上り，局所根治照射の条件として は照射出力2.0W，総照射時間15分間以上，総照射異 1500 J/cri以上さした。台併症のために乎街不能な4症例に 対し，局所根治照射在施行したとこ万，4例全例が生娭 癌陰性之なり。全例1年以上の再発在みていない。以上

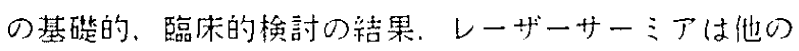
照射法に比べ，同等以上の照射効果索有するばかりでな

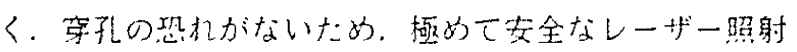
法として今徭期待できるものと考元ら机る。

シンボジウム $2-6$

6. 呼吸器科領域に戈ける レーザーサーミアの試み

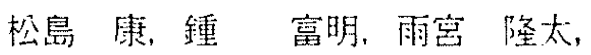
於保 健吉, 早田 義博 東京医科大学外科

肺は呼吸遇動と肺偱獧による人体の中の巨大放熱器官

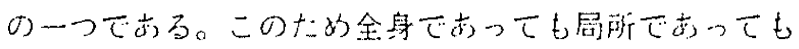
温熱療法の効果の薄い領域である。我々はレーザー装置 
と脾光ファイバーを工夫することにより，呼吸器領域へ の局所温熱療法の可能性を基䃈実験および臨床例で検討 した。基礎実験：1）豚肝葳を用いてプローベとしての 登光ファイバーの有用性の検討。2) 豚肝臟を用いて レーザー出力および照射法の検討。3）ヌードマウス移 植腫境を用いて抗腫湯効果の検討。4) ひと切除肺を用 いて経気管支的レーザーサーミアの検討。結果：1）単 石英ファイバーと，SLT ジャパン製セラミックロッド が㛟討された。セラミックロッドは硬度、耐熱性に侵れ るが、光ファイバーとの接合部を組織内に入れて使用 するため。頻回使用でこの部分が熱により緩む場合があ り、まだ改良の余地を残した。石英ファイバーは先端 カッティングの仕方でレーザー放射角を調節でき、カッ ティングも容易なことから、臨床にはこ机を用いた。 カッティングは尖型が良く，さらにレーザーの放散を多 くするため，先端をペーパー等で研磨することが望まし い。2 ) レーザー発生装置の性質上，5 W以下では不女 定になることと， 5 Wで内部炭化が最小の蛋白变性を得 ることができることからここの出力で行った。照射方法 は連続よりも1〜2秒の間歇照射が有効であった。奏質 臟器での実験では、 $43^{\circ} \mathrm{C}$ まで上昇するのにプローブ中心 から $1 \mathrm{~cm}$ では 5 ～8分であったが. $2 \mathrm{~cm}$ 離机ると10分以 上を必要とした。3) 移植腫瘍では， $5 \mathrm{~W}, 100 \mathrm{~J}$ の照 射で直径 $8 \mathrm{~mm}$ の蛋白变性と睡瘍壊死が得られ，中心部炭 化もみられなかった。しかし，辺緑部にはvaiableな組 織を認めた。4)切除肺では、プローブで気管支壁を貫 通する際レーザーを低出力で持続発射させておくこよで 容易に通過させることができた。また $5 \mathrm{~W}, 100 \mathrm{~J}$ の照 射で肺実質に約直径 $5 \mathrm{~mm}$ 大の蛋白变性層が得られた。た だしプローブの刺入深度に対するメルクマールがないた め、これに対するプローべの改良の必要性が示崚された。 臨床例：現在までに肺癌 2 例、肺癌の胸壁及心゙皮商移転 例 3 例，他良性腫澛 1 例の治療を行った。いくつかの症 例を提示する。1) 左肺扁平上皮癌で下葉切除後の背部 肋骨及び胸壁転移例。転移部位が広範な大め $2 \times 2 \mathrm{~cm}$ 大 のマス目を作り1マスに2〜3 ケ所のレーザーサーミア を1/週で 4 週間行った。平均出力は 5 Wで1回約20分 行い同時に 5 週間ライナック46GYの照射治療を行った。 この結果腫絙縮小著明で、外科的切除が可能亡なった。 2 ) 右中葉末梢の扁平上皮虞例。街前に経皮的肺穿刺を 行い，5W，20分の治療を行った。切除肺では組織学的 に壊死，緎維化を認めるものの，周辺部ではviableな
組織像を示した。この治療により気胸を生じたが、胸腔 内出血はなく、また脱気、ドレナージの必要もなかった。 これは穿刺部周囲の蛋白变性により空気漏出や血管が シールドされたためと考えられた。3）左 $\mathrm{S}^{6} の$ 扁平上 皮癌の壁外リンパ節。経気管支鏡的にリンパ節第刺を行 い。 $5 \mathrm{~W}, 20$ 秒の治療を行った。切除肺でリンパ節の大 部分は壊死，織維化を起こしていたが，周囲には直径 2 $\mathrm{mm}$ 大の血管を認めた。考案：以上の実験お上び躁床経験 から次のようなことが考えられた。現実問題として呼吸 器科領域における，有効な局所温熱療法がない現在, 蛋 白変性が主体ではあるが、目的部位への的確な加温が可 能なレーザーサーミアは，有用な治療法の一つと考える。 しかし治療筙囲が㹟いことから，他療法との併用が望ま れる。その対象は，大血管損賃の危険珄のある肺門部を 除き，ほぼ胸部領域全般の腫演にわたると考える。特に 今まであまりできなかった壁外りンパ節の治療には期待 がもてる。ただし，壁外血管の損偒の危険性があり施行 前の周囲状況の充分な把握が必要であると同時に、レー ザープローブなどの改良工夫が待たれる。

\section{シンポジウム $3-7$}

7. 子宮頸部前癌及び初期癌に対する レーザーサーミアの適応

木附 公介, 清木 康雄, 佐野隆, 植木 実, 杉本 修 大阪医科大学産科婦人科学教室

黒川 彰夫 大阪医科大学病理

大工園則雄 エス・エル・ティ・ジャパン

目的：子宮頸部前癌及び初期癌の発見率が高まり，六 つ若年化䝨向にあるため. 千宮保存療法が要求されてい る。教室では1983年よりYAG-lasar 円錐切除術を行い， 良好な治痖成綪を得てきた。そこでこの治療法をさらに 発展させるために、非觀血療法としての laserthermia の基礎的研究を行ってきた。今回. 新たに高搪散 probe と reflector 在開発し、非接触法在併用した照射法を考 
案した。そこで、この照射法を子宮頸部前癌及び初期癌 に臨床応用し, laserthermia の治療勃果を知る目的で。 病理組織学的娭討を行った。

対象亡方法：laser 発生装置はSLT-Japan 社製 CL 50 と SLT Feedback laserthermia System を用いた。 照射には，laser 光を主に横方向に照射するように開発 したS LT Frosted Probe と, laser 光を反射させるよ うに金メッキした円錐型の reflector を用いた。この照 射法による局所温度分布を摘出子宫頸部を用いて，出力 $3 \mathrm{~W} ， 20$ 分間照射し．多点同時測定し検討した。照射対 象は軽度異形成 1 , 高度異形成 2 , 上皮内癌 3 , 微小浸 潤癌 6 例の計12例である。条件は出力 $3 \sim 4 \mathrm{~W}$ とし, 病 变辺縁部 $42 〜 43^{\circ} \mathrm{C}$ C20分間維持した。また照射は 1 回の みとした。全例 1〜8日後にlaser 円錐切除を施行し， 摘出摽本を病理組織学的に、また一部には電顕にて観察 した。

結果：摘出子宮澒部における局所温度分布は, probe から半径 $8 \mathrm{~mm}$ 以内では約 $50^{\circ} \mathrm{C}$ 以上, その周囲の probe から半径 $15 \mathrm{~mm}$ の籍冊が41〜43ㄷに保たれていた。laserthermia 後の病理組織学的变化は. probeに近接した $50^{\circ} \mathrm{C}$ 前後の高温域の組織は壊死に陥っていたが, その周 囲の組織では経時的に䱰々の変化が認められた。即ち， 5 日後の前癌病变では水抱形成部位と, 中層に当たる細 胞が壊死に陥り，空淂走示している部位とが観察された。 5 日後の初期癌でも同様に，細胞間結台が粗になったり． 一部では壞死に陥いる表層の变化が認められた。 また上 皮直下の毛細血管が搪張し，血栓の形成や，上皮直下に 高度な出血が認めら机た。8日後の癌細胞の大部分は变 性に陷っており，核内空胞や細胞質内の空胞が目立ち。 核の膨化，核濃寉、核融解など多彩な变化が認められた。 一方. 光顕レベルで变化がないと思わ机た癌部位も電顕 で観察すると、袖胞間は離開し、かろうじて desmosome 結台がみられ。また，癌䄄胞の細胞質には細胞小器官が 殆ど認められず、ただグリコーゲン顆柆と ribosome 及び小空胞が散見さ机るに過ぎなかっだ。

結論：非接触方在併用した照射法は，広範囲に安定し た温度コントロールが得られ，子宫臸部の加温に適した 方法である。経時的な病理組轼学的検討で, 前癌病变や

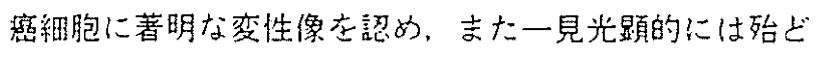
变化がなかった癌細胞でも。すでに電顕レベルでは变性 京来しているという極めて與昧ある所見が得られた。 以 上よりYAG：laserthermia は子言頸部前癌及び初期
癌に対する非観血療法として今後有用な治療法になり得 ると考えられた。

\section{シンポジウム $3-8$}

8. 脳腫瘍に対する laserthermia

藤島一郎, 堺 常雄

聖隷三方原病院脳神経外科

杉山 憲嗣, 龍 浩志, 植村 研一 浜松医科大学脳神経外科

外科的治㞠の困㨷な深部脳腫瘍に対する新しい治療法 開発の試みとしてNd：YAG laserを用いて脳の深部 照射を試みてきた”。今回はlaserを低出力で使用する レーザー温熱療法 (laserthermia) との比較を行い新た な知見を得たので報告する。

方法 猫50匹を用いた。ネンブタール麻醇下に猫の頭 部を定位脳手術装置（成茂 $\mathrm{SN}-3$ ）に固定し, micromanipulater にquartz fiberを固定し，脳哚部に誘翠。 laserを照射した。(1) 7 -15Wで1-5分の連続照射 (FUJINON YAG Laser FYL-M 1 及びMedilas YAG Laser 使用. quartz fiber 先端は凸面加工)。(2) 2.5-3 W. 30分の Laserthermia (SLT Laser CL50. Computer Control Laser-thermia System. $3-5 \mathrm{~mm}$ SLT frosted fiber tip 使用, 周辺温度 $43.0^{\circ} \mathrm{C}$ ) 行い 経時的に屠殺し，HE染色にて lesion を観察した。なお， Laserthermia 終了直後に Trypan Blue を静注し脳血 管関門(BBB)の状態を観察した。

結果 $7-15 \mathrm{~W}$ 連続照射; 中心部は蒸散し空洞形成。 周囲に炭化層, 壊死層、浮腫層を形成。24時間から48時 間にかけて白貿中心に強い浮腫層が広がり壊死層に点状 出血が生じた2)。laserthermia；中心部は凝固壊死層 であり炭化層の形成無し。 $43.0^{\circ} \mathrm{C} の$ 加温範囲に一致して 僅かに浮腫層を認めた。24-48時間経過後に浮腫層の広 がりを見たが局所によじまっだ。 $43.0^{\circ} \mathrm{C} に$ 加温しだ範囲 は，Laserthermia 終了後に静注した Trypan Blue で リング状に染まり加温した脳組織の BBBが openする ことを確認した。

考案 Nd：YAG Laser は凝固. 止血作用に绶狆， 
細いquartz fiberで紫光できるため扱いやすく，脳深 部への誘埒も容易である。徉来外科的治療の困難であっ た深部脳腫瘍に対して中心部から凝固蒸散するNd：YA GLaserの深部照射は多いに治療効果が期待できたが， 術後に生じる脳浮腫が問題であっだ”。こに対して Laserの出力在 2-3Wで用いる laserthermia は脳浮 腫を最小限に抑えることが出来た。また加温筙国のBBB が openすることにより抗癌剂を併用すれば腫痛のみに 畐濃度に集皘させることが期待できる。

脳腫瘍に対する温熱療法はろ Microwave, Radiofrequencyなどを heat source として成果を挙げてい るが, 脳深部の正確な局所加温は困難である。laser を用 いた局所温熱療法は ceramicsを用いた高应散 microrod と computerを受入した制御システムの開発により正 確な温度制御が行えるようになった。脳神経外科領域で はCT guided stereotactic methodを用い脳深部の lesionに対しても正確な加温が行える。現在，基䂣実 験をもとに臨床芯用を行っているが良好な結果を得てい る。

結語 脳腫瘦に対する laserthermiaは安全性も高く 今後の臨床応用に期待が持たれる。

\section{文献}

1) 藤島一郎, 龍 浩志他：Nd-YAGレーザーによる 脳深部照射の基礎的実験. Neurol Med Chir (Tokjo) $26: 621-627,1986$.

2 ) 藤島一郎, 堺 常雄他: Nd-YAGレーザーによる 実釦的脳深部照射一急性奏験上慢性奏験の比較. 日本 レーザー医学会誌 7(3):77-78, 1987

3) Salcman M. Samaras GM, et al. :Hyperthermia for Brain Tumor:Biological Rationale. Neurosurg. $9: 327-335,1981$

4) 鈴木荘太郎. 青木 純他: 内視鏡下Nd-YAGレー ザー温熱療法に関する基䂣的研究及び制御システムの 開発. 日本レーザー医学会誌6 (3):347-350. 1986

\section{招待講演}

Hyperthermia Potentiation of Photodynamic Therapy Employing

Photofrin I and II: Comparison of Results Using Three Animal Tumor Models

Stephen M. Waldow, phD.

Wenske Laser Center, Department of Surgery Ravenswood Hospital Medical Center, Chicago, Illinois

Hyperthermia induced by a microwave source $(2.450 \mathrm{MHz}$ ) was used alone and in combination with photodynamic therapy (PDT) to treat the SMT-F, EMT-6, and RIF animal tumors in vivo. PDT was administered using either Photofrin I or II as the photosensitizer and an argon-pumped tunable dye laser $(630 \mathrm{~nm})$ as the light source. Greater than additive increases in long-term tumor control were achieved when hyperthermia was given immediately post-PDT in the SMT-F and RIF tumor systems. Only additive (or independent) increases in tumor control were achieved when hyperthermia was given immediately before PDT in all these tumor systems and when heat was applied post-PDT using the EMT- 6 tumor.

In a series of experiments using the SMT-F tumor, it was observed that decreases in PDT drug or light doses could be offset (in terms of tumor control) by the addition of subsequent tcat treatment. This result, along with others presented, indicates the clinical potential of PDT and hyperthermia as adjuvant cancer modalities. 


\section{レーザ一関連学会報告}

第3 回 レーザーサーミア:シンポジウム

会 期：1989年8月26～27日

会 場: 名鉄犬山ホテル（犬山市）

世話人：恒川洋

〈プログラム〉

シンポジウム1「レーザーサーミアの基礎と臨床」

座長：福富久之．鈴木荘太郎

(以下・数字は抄録の掲載順番)

1. 田尻, 2. 平井. 3. 青木. 4. 印牧. 5. 西福.

6. 清水. 7. 昇. 8. 堺. 9. 安藤. 10. 清水

特別発言: 小黑八七郎

シンポジウム２「ND：YAGレーザーを用いた光化学 治源（光線力学的治療）に関する研究」

座長：比企能樹，堺常雄

1. 藤島. 2. 伊奈. 3. 中沢, 4. 山下, 5. 古賀,

6. 荻野， 万. 森山. 8. 西脇, 9. 渡辺

特別発言：磨伊正義

一船演題 1

座長：昇卓夫.ニツ木浩一

1. 鳴海. 2. 竹内. 3. 間宫, 4. 藤田 一般演題 2

座長：清水正娟。伊藤克昭

1. 渡辺. 2. 渡辺. 3. 小野. 4. 吉田. 5. 下元 特别講演(抄録なし)

1。菊地埧：レーザーとハイパーサーミア（座長：斎 藤英彦

2. 渥美和彦：レーザ一治療の現状上将来（座長：八 木国夫)

3. \#田和徳：早期胃癌に対する内視鏡治療の現状と 対策（座長：春日井達造）
〈抄録〉

シシンポジウム $1-1$

レーザーサーミアの作用機序に関する

基礎的研究

田尻 久雄, 小黑 八七郎

国立がんセンター病院内科

レーザー温熱療法の作用機序を明らかにする目的で, マイクロ波温熱療法と対比し基礎的検討を行った。 ヒト 膵癌由来のヌードマウス移植腫瘍に両治療法を行い，7 日後の病理組織学的变化をみると，両者ともに広範囲な 凝固壊死が認めら㣗た。一方，治療直後の細胞レベルの

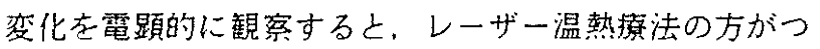
よい鹪害をうけていた。また，in vitroにて腫動細胞の 伤害性を比較した結果、レーザー温熱療法が最も著しい 殺細胞効果を示した。従ってその作用機序亡して，局所 の温熱効果及びND：YAGレーザーの光作用により腫 瘍細胞が㒐害され，その後に引き続いて起こる血管系の

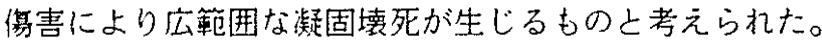

\section{シンポジウム $1-2$}

非接触レーザー照射法による内視鏡的 温熱療法の基礎的・臨床的検討

平井信二, 桯村 博正, 堀田 総一, 中原朗, 福富久之

筑波大学臨床医学系内科

基砶的検討では，非接触レーザー照射法に上る局所温 熱療法は，広範国の安定した局所加温が可能であり、深 部加温効率の点から，YAGレーザーが最も局所温熱療 法には適していた。更に、移腫噋腫䒔用いた。レーザー 温熱療法の抗腫㷎効果は良好であり，化学療法棛老併用 することにより，その勃果は更に増大した。また、組織 学的娭討からは，血管系在介した抗腫激效果の閏与が推 
測された。

臨床的検討では，早期胃痦に対するレーザー温熱療法 の効果は不十分でまり，現状の温度制御系には問題点は 残すが、蒴独では局所根治は困難と思われた。進行胃癌 に対する化学療法レーザー温熱療法は，有効な内視鏡的 治療手段の1つになると思秃れが、反復治黁の必要性 を痛感した。

\section{シンポジウム $1-3$}

消化管内視鏡治療における Laserthermia

青木 純, 鈴木 荘太郎。

鳴海 裕之

東海大学医学部内科 6

基礎的検討方よび臨床応用の結果.

(1) 局所温度コントロールは， computer systemによ

り容易かつ確実となった。

(2) 局所温度分布は，照射中心部か $50^{\circ} \mathrm{C}$ 前後直径約 $10 \mathrm{~mm}$ の範囲は42〜 43ㄷ゙あった。

（3）組識変化は， $3 \mathrm{~W} ， 10$ 分の条件にて粘膜下層の上部 まで認めた。さらに，粘膜下層の且菅内での血液凝固 を諗的。効果発現への関与が示惨さ㣗た。

（4）実験胃腫湯に対する温熱照射の結果，腫湯䈹小効果 が認められた。

(5) 隆起型應に有効であること，化学療法との併用に 上り腫瘦粳小効果があることが確認された。

(6) feedback sleeveを用いた 1 channel 方式存開発し.

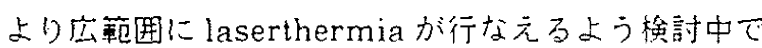
ある。
シンポジゥム $1-4$

Nd：YAGレーザーサーミアに関する

病理組織学的検討

印牧 直人，岸 克彦，中澤 三郎 藤田学園保健衛生大学内科

恒川洋 名鉄病院消化器科

laserthermia の腫激破填の機序を明らかにするため。 in vivoに执い下光影的・電䡩的に娭討した。Lewis 肺 癌度皮下移植したBDF，マウスに対して照射出力2.0W $43 \pm 0.5^{\circ} \mathrm{C}$ の条件で10分間レーザー加温を施行し. $43^{\circ} \mathrm{C}$ の部位の組織变化を検菜した。【結果】1)光影像：照 射直徭上り腫痔内および周囲血管の管血像がみら机た。 3 時間後に出血が著明よなり。6時間後には細胞の变化 が明らかとなった。24時間㣪，出血性壊死像を呈した。 2 )電顕像：照射直後よりミトコンドリアの膨化・破填 がみら机た。葹の変化は3時間後上り出現し，6時間䌽に はクロマチンの㠜集化が著明となった。24時間後、核は破 壊さ㣗. 細胞質は空胞変性を示した。【結論】laserthermiaによる最初の变化は，細胞内小器官のミトコン ドリアである可能性が示唆さ机た。

シンポジウム $1-5$

散乱物質在用いたバルーンレーザー 温熱療法（第二報）

西锚 幸二, ニッ木 浩一 埼玉がんセンター・消化器科

我々は昨年の当シンポジウムに执いて進行癌治療に店 用可能なNd：YAGレーザーを用いたバルーンレー 壮一温熱㞠法在考案し，その基整的検討在行い報告した。 今回は治療温度之治療時間之の関係について蚞討し温熱 療法の特異的治療効果在再確認できたので報告した。対 


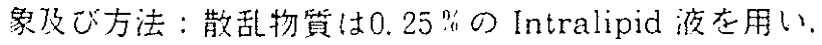
バルーンは市販のコンドームを材料にして作成した。対 象はマウスに移植した Neth-A Sarcomaを用いた。結 果及び考察：移植腫瘍の壊死性变化!+設定温度之照射時 間に比例して增加した。治療時間よしては。20分間治癔 した場合に40.0-40.5 $5^{\circ} \mathrm{C}$ 上 $42.5-43.0^{\circ} \mathrm{C}$ での治療效果に 著しい差在認孙た。即ち，本法は良来の温熱痖法に認め ら机た特異的な治療効果が期待できることが明らかと なった。

シンポジウム1-6

口腔外科領域におけるレーザーサーミア についての若干の知見

清水 正翤司

大分医科大学速科口腔外科

レーザーサーミアに限らず温熱療法全般を通じ，口腥 外科領域にそ机を奏施するにあたって問題点として (、1) 症例の選抧，2）条件の設定上実施方法。 3) 効果の判定.などがあげら扟る。今回のシンポ の発表でも方法の選択として，Nd：YAGレーザー サーミアの接触法。韭接触法にわけ、レーザーバ

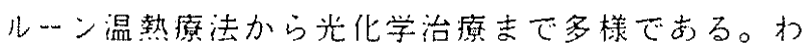
扎机が奏施しているNd：YAGレーザーサーミア

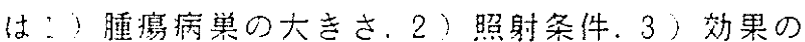

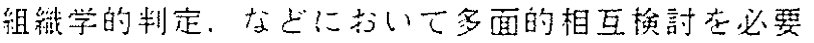
とする段階である。こ机に対応する動物奏験が必瑟 之考元開始したが。その予備的成績は教宝の小野が 明日発表する。最俊に新しい治験例として，82歳女 性宮滆平上皮癌 T 3N1MO例のレーザーサーミア奏施

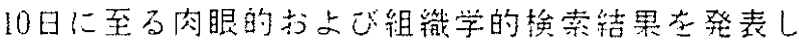
た。

\section{シンポジウム1-7}

術前治撩におけるレーザーサーミアの評価

䒜卓夫

鹿児島大学耳鼻咽喉科

過去 5 年間に，放射線㿑法，化学療法にレーザーサー ミアを例用したT2.T3症例，9例の衍徭の病理組織

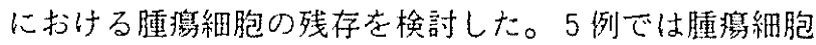
の残存は認められず、残り4例では腫㾿細胞の残存が認 めら机た。症例数は未だ少ないので断定的なことはいえ ないが，従来の三者侀用療法にレーザーサーミアを仵用 することで，放射線量や薬㖁量の減量が期待できること が示された。T 2 症例では1例を除き腫激細胞の残存は 認めず，T 2 では放射線量はもっ上減量しても良いので はないかと考えられた。また場合によっては，街後の不 要になる可能性も示㖫された。一方では，T 3 症例 4 例

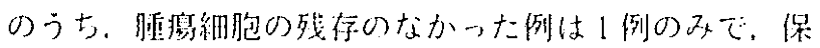
存的治摬心困萁さ，限界を示しているものと思われた。

シンポジウム1-8

脳神経外科におけるレーザーサーミア

堺 掌雄, 藤島一郎，杉山 慧嗣* 聖隷三方原病院脳神経外科 *浜松医科大学脳神経外科

1087年上り深部脳腫郻に対してND：YAGレーザー による interstitial laserthermia を行ってきたが、こ れまでのまとめと今後の閣題点について述べる。

安全性を確認するために動物実娩を施行, laserthermia による譄の組織的变化，脳組織内における温度分布を調べ た。次に化学㩒法の可能性老知るためにlaserthermiaに よるBBB (blood-brain barrier)への影響を調べた。

laserthermiaにより中心部は凝固壊死となりその周 辺に僅かの浮腫がみら机た。温度分布は probe 在中心 
とした棈円体状の分布となっだ。BBBは照射後 6 日間 障害さ㣗た。

䠦床応用は6 例（glioma 3 例，転移性腫暍 3 例）で 行った。CTガイドにより定位的に interstitial probe を腫瘦内に刺入，周辺部の温度は温度サンセーを用い 42. 5-43.5 $5^{\circ} \mathrm{C}$ にコトロールし $2-3$ watt. 30-45分間照 射した。1例老除いて全例で照射德に化学㞠法老併用し た。結果は神経学的所見とCTスキャンの follow-upで 判定した。街後一過性の神経症状の增恶はあるものの軽 快し、1例を除いて腫瘍の消隇または篗小をみた。

問題点としては cystic tumor の場台の適応亡，術中 の温度モニターの重要性があげられる。

結論として.Nd：YAGレーザーによるlaserthermia は脳腫癔の治療に対して有効である。

$$
\text { シンポジウム } 1 \text { - } 9
$$

眼瞼悪性腫瘍の放射線療法に対する レーザーサーミアのアジュバント効果

\section{安藤 文隆}

国立名古屋病院眼科

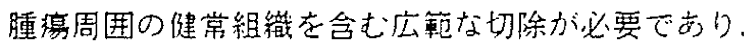
眼眙再建術の問題も伴う眼眑のマイボーム氏腺眼に対し， レーザーサーミアを試みた。1回15分（42〜43ㄷ加 温）のレーザーサーミアを 2 週間隔で 3 回施行したとこ ろ、腫演は触机なくなっていたが，約100月後再発し， 徐々に增大した。最初のレーザーサーミア施行から約20 力月㣪に再度レーザーサーミアを試みたが，2回目の レーザーサーミアは全く無勃で，腫舅は著明に增大した。 そのため，陽子線総量63.0GYの放射線法在行い，著効 を得た。

この経験をもとに，40才女性のマイボーム氏腺癌に， 1 回20分のレーザーサーミア妾 2 回施行後, 陽子線総量 $50.6 \mathrm{GY}$ の放射線療で治療し，よい結果を得た。レー ザーサーミアの前処固が放射線療法に有効と思われた。
シンポジウム $1-10$

子宮頸部前癌および初期癌に対する

レーザーサーミアの基礎と臨床

木附 公介, 清水 康雄, 御前 治,

植木実, 杉本修

大阪医科大学科婦人科

laserthermiaに掞いてより広範囲な加温領域を得る 目的で，我々が開発した reflectorに ballon 法を併用 する接触法を考案した。本法を子宫頸部前癌及び初期癌 に臨床応用し，その勃果を病理組織学的に蚞討した結果。 reflectorのみの非接触法に比して有効であったので報 告する。

照射は，円錐型のreflector前面にラテックス製フィ ルムを張り，その中に散乱物質として0.125\%のイント ラリッピドを注入し，患部に接触させて行なった。温度 は thermocouple reflector 外側縁で約 5 喵刺入し， $43^{\circ} \mathrm{C}$ 維持した(出力約 $10 \mathrm{~W}$ )。

組織学的所見では, ballon 接触面に一致して表層上 皮病变の変性が見られた。また，非接触法では見られな かった腺侵篮部位の病変でも浅い部位では変性が見られ た。しかし接触面の中心部では過度な温度上昇によると 思われる変化があり，さらに効果的な散乱物質で開発が 望まれた。

シンポジウム $2-1$

Nd：YAGレーザーとPhAによる

光化学療法の基礎研究：HPLCを用いた

PhAの臟器内濃度測定

藤島一郎, 堺常雄,

堀内健太郎 ${ }^{*}$ ，杉山 憲嗣**

聖隷三方原病院脳神経外科

$*$ 浜松医科大学化学 $* *$ 脳神経外科

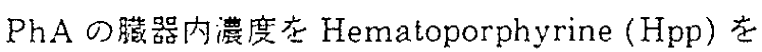


internal standardとして用いることにより比較的簡便 で正確に測定する方法を確立した。方法：F-344 rats の視床に Rat T9 Glioma ( $1 \times 10^{6}$ cells, 12days)を移

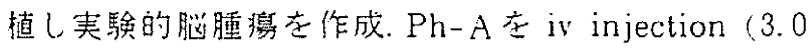
$\mathrm{mg} / \mathrm{kg}), 24 \mathrm{hr}$ 㣪に菱器 (0.1-0.5 g) をとり。Aceton (85光) $5.0 \mathrm{ml}$, Hpp $25 \mu 1$ と混台し Homogenize。上澄 老 sodium sulfate ethylacetateにて抽出してHPLC で分析。Hppの回整率からPhAの㻎在测定した。結 舁：既知のPhA在加えて、この方法で分析した結果は 是妒であった。脳腫瘦には63ng/g，周围脳には8. $4 \mathrm{ng} / \mathrm{g}$. 反対側脳には3 $\mathrm{ng} / \mathrm{g}$ 以下のPhAが娭出さ㧈た。榕器内 のPhAの絶対值を知る方法として有用である。

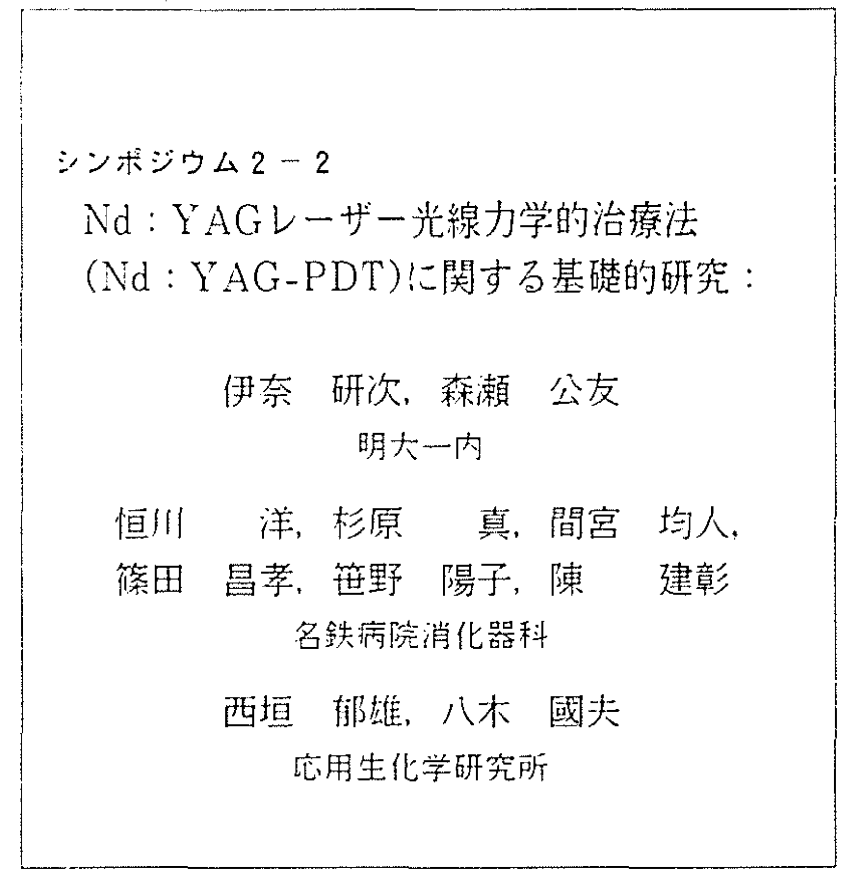

我々は1987年以来 Nd：YAGパルスレーザーと光增 感物䈱 pheophorbide a (ph-a)に上る光線力学的治療

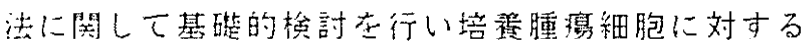
ph.a投与下でのレーザー照射が强い殺細胞効果を有す ること坴明らかにした。吉た ph-aの存在あるいは非存 在「にレーザー照射を行い，照射誖の細胞内過酸化脂貿 量桨測定した㸵果，ph-a存在下にレーザー照射を行っ た琻でのみ有意に過酸化脂筫量が上昇した。次にこの PDT心殺槒胞效果のメ力二ズ么在解明古万目的で。

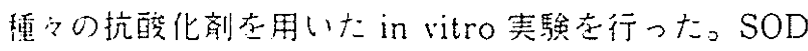
投学群在除き。生存率が著しく上昇したことより.PDT に上り菣起さ机る過酸化反応は singlet oxygenに基づ ‘ type II の光化学反萎ばかりでなく radical 反店です
る type Iの光化学反応の関与も推測された。

シンポジウム $2-3$

pheophorbide-aによるNd-YAG-PDTの 基礎的敛討

中澤 慶彦, 門脇徹, 西岡隆見

高橋 佳伸, 宮田彰, 坂本芳也,

中田博文, 森田雅範, 圆崎 和一,

山本 泰朗, 山本 泰猛

高知医科大学第一内科

(方法) (1) PpA濃度 $0-250 \mu \mathrm{g} / \mathrm{m} 1$ にて $4 \times 10^{4}$ cells/well (culture area $0.32 \mathrm{cmi}$ )を 2 時間培黄後，上

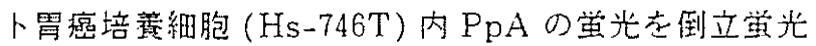
㩆微鏡. 顕微鏡用テレビカメラおよび画像解析装置にて 解析し, 細胞内濃度在測定。(2) Q-switch YAG-Laser (SLT-Japan, CL50.200pps, 平均出力1.5W) 在 1-5 min 照射後，殺袖胞効果 MTT assayにて梌定した。

(結果) (1) PpAは細胞筫に均一に取り込ま机、細 胞内濃度は29.2 $\mu \mathrm{g} / \mathrm{m} 1$ (Medium $10 \mu \mathrm{g} / \mathrm{m} \mathrm{1}$ ). 116.4 (50), $122.8(100), 126.5$ (250) であった。(2) PpA 単独で殺褔胞效果あり。さらにLaser 照射時間(1.3.5 $\min ), \operatorname{PpA}$ 漂度 (50.100.250 $\mu \mathrm{g} / \mathrm{m} \mathrm{1})$ に比例して殺 細胞効果の增加を認めた。

シンポジウム $2-4$

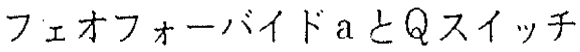

Nd : YAGレーザーによる光線力学的治療

についての基碟的検討

$$
\begin{gathered}
\text { 山下 幸孝, 森安 史琪 } \\
\text { 京都大学第一内科 }
\end{gathered}
$$

酒井正彦 同中央桙查部

肝細胞癌移蒀ヌードマウスにフェオフォーバイド 
a (Ph-a) を投与し，腫演内潾度を高速液体クロマトグ ラフィーを用いて测定した。

その結果，(1) $1 \mathrm{mg} / \mathrm{kg}$ 経口投与群，0.009 $00.007 \mu$ $\mathrm{g} / \mathrm{g}$ (2) $250 \mathrm{mg} / \mathrm{kg}$ 経口投与群, $0.22 \pm 0.06 \mu \mathrm{g} / \mathrm{g}$ (3) 5 $\mathrm{mg} / \mathrm{kg}$ 腹腔内投与群, $0.85 \pm 0.14 \mu \mathrm{g} / \mathrm{g}$ (4) $200 \mu \mathrm{g}$ 腫㾤 内局注群。非局注側 $3.42 \pm 2.84 \mu \mathrm{g} / \mathrm{g}$. 局注側 $116 \pm 24$ $\mu \mathrm{g} / \mathrm{g}$ で，各腫港に対して，0.5W，10分間Qスイッチ Nd：YAGレーザー組織内照射をしたところ、コント ロール群に比し、Ph-a 投与群の腫湶壊死面積が大き かったのは，(4)腫瘍内局注群のみであった。これらより， 光化学反応は，腫演内 Ph-a 濃度が $0.85 \mu \mathrm{g} / \mathrm{g}$ 以下では 充分起こり得ず，少なくとも数 $\mu \mathrm{g} / \mathrm{g}$ 以上のPh-a 莀度 を必要とすることが明らかとなった。

\section{シンポジウム $2-5$}

KATO四細胞における Pheophorbide-A のとり込み，細胞内分布とオルガネラの 障害

$$
\begin{gathered}
\text { 古賀 俊彦”，仙頭 聖一”, } \\
\text { 中村 三干男” } \\
\text { “古賀病院 “東大医科研 }
\end{gathered}
$$

ヒト印罢細胞癌由来の培細胞力トウ而を用い。フェ オフォーバイト(Pha)の取り込み・分布在，又．光酸化 後の細胞形態の变化を，蛍光顕微，光顯．電顕的に，又 フローサイトメトリーを駆使して検討した。

1) $\mathrm{Ph} \mathrm{a} の$ 細胞内取込みは，温度及び時間に依存し， エネルギー非依存性で，Ph a の濃度により，多く取り 计声扣るが，一定濃度を越えると緩やかになる。死細胞 により多く入り込む。2） Phaは細胞内では：ミトコ ンドリアに特異性はなく，核をある程度避け。細胞質内

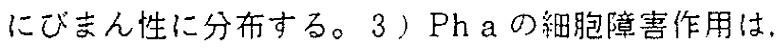
光酸化作用である。4)光酸化反応後の細胞增殖は，コ ントロールと比較して．S期（DNA台成）の障害を認

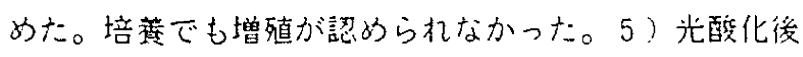
では，生細胞の原型を保つ細胞が有意に減少し、変性の 著明な細胞や中等度障害の細胞が増加した。これらは細 胞膜の不明瞭，核膜の切扟込みの減少，核縁のスムース
化が見ら机，電顕所見では，細胞内構造物の無搆造化， ミトコンドリアのクリステの变性・消失がみられた。

シンポジゥ公 2 - 6

Nd：YAGレーザーによる光線力学的治療 一特に抗癌剤之の併用治療についての 基礎的研究一

荻野 知已，沢口潔，出口 康， 䵇伊 正義

金沢大学がん研究所外科

人瘵細胞樹立株，KATO-杰に対寸る，Ph-a，1時 間接螌による濃度反応曲線を 3 日後に MTT assayに て挨討した。またMMCの濃度反応曲線から至啇濃度上 して $6 \mu \mathrm{g} / \mathrm{ml}$ 求め, $\mathrm{Ph}-\mathrm{a}(10 \mu \mathrm{g} / \mathrm{ml})$ 上の併用効果, レーザー照射による“PDT”勃果を検討した。MTT assayではPh-aによる增殖㧕制効果のみがみら㣗。 レーザー，MMCの併用効果はみら机ず，一方，照射 1 時間後のDye exclusing method では全く殺細胞効果 が認められなかった。次いで, Ph-a濃度老50// g/ml, $100 \mu \mathrm{g} / \mathrm{ml}$ に増加したところ, MTT assayではPh-a 濃度に比例した強い細胞增殖抑制のみが見ら机たのに対 し. Dye excl. ではレーザー照射の相加効果(PDT)がみ ら扎た。PDT効果判定に問題があると思狆た。Ph-a 溶解法にも問題点が見ら扎た。

シンポジウム $2-7$

HEp 2 細胞に対するPDTと温熱療法

$$
\begin{gathered}
\text { 森山一郎 } \\
\text { 鹿児島大学耳昇咽喉科 }
\end{gathered}
$$

Nd：YAGレーザ一光は安定した熱の供給源であり。 外科的切開の他にも癌温熱療法すなわちレーザーサーミ アとしても用いら机てきた。一方. Nd：YAGレー 
ザー光はパルス波で瞬時に高出力発する $Q$ スイッチを 装着することにより，クロロフィル誘覃体のフェオ フォーバイドa（PH a) の励起光として作用することが 知ら机ている。今回. $\mathrm{Nd}$ : Y Y A Lレザーのこれらの 特性を利用し，上卜喉頭類表皮癌由来の $\mathrm{HEp} 2$ 細胞に 対し光化学療法(PDT) 上温熱癔法上を併用した。PH a の HEp 2 細胞に対する毒性試験では， $0.5 \mu \mathrm{g} / \mathrm{ml}$ ( $\mathrm{PHa} / \mathrm{PBS}$ )以下の濃度での安全性が認められた。また。 その結果在踏文。 $0.5 ! 1 \mathrm{~g} / \mathrm{ml}$ (PHa/PBS)の濃度で 2 時間培責後. PDTとPDT+温熱療法を行ったが、と もに細胞增殖の抑制が認められた。なかでも，温熱療法 との併用では。续とんどの細胞が死隇した。

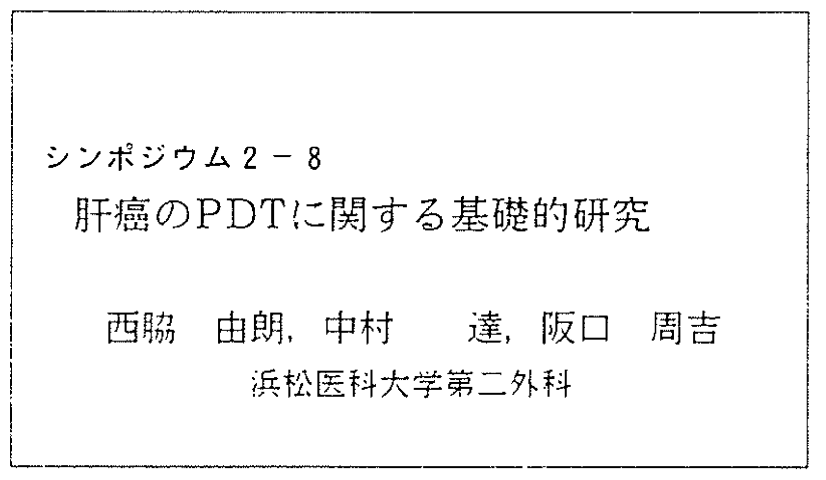

HPDは静注すると撚により肝・腎により多く集辕す るため，光照射に上り正常肝も障害を受ける。我々は Lipiodol (LPD) が肝動脈より注入すると肝癌に集積す ることを利用した。 pheophorbide a (Phd)にLPDを 打元てLPD-Phd 存.PBS心溶解して水溶性 Phd (W-S Phd)在調台した。象の肝にVX 2 痖在移植し. LPDPhdとW-S Phdを動注. W-S Phd 青争注して〔1 mg / kg) $24 \mathrm{~h}$ 後に体内分布を比較した。動注では癌のPhd 濃度が有意に肝上り高く，LPD-Phd 動注では皮苻から は椎出さ机なかった。静注では肝脾が有坛に癌上り高 がた。次にSD ratにWalker腫謴老移植し. Phd を 動注・静注で投与し(0.25mg/ kg) $24 \mathrm{~h}$ 娞 Nd：YAG Dye Laser $(670 \mathrm{~nm})$ 在 $200 \mathrm{~J} / \mathrm{cm}$ 照射 L. $24 \mathrm{~h}$ 㣪屡殺 $\mathrm{L}$ 比较した。動注群は正常肝在弈害せず腫湯に著明な壊死 を生じた。静注群では腫瘦罱死主生じなかった。

\section{シンポジゥム2-9}

光増感物質フェオフォルバイドaについて

渡辺常一, 木村一雄, 大村浩 (䏭りクルト本社中央研究所

近年.フェオフォルバイドa $(\mathrm{PPBa})$ は. 光化学療法 に有効な光增感物質として注目さ机ている。今回は、ク ロレラから分離したPPBaの定量法および諸性筫につ いて検討したので報告する。PPBaの分離定量には TSK gel-ODS80TM を用いた HPLCが有効であり， ピロPPBaならびに10-ヒドロキシ PPBa と効率息く 分離することができた。また，上記 HPLCに方いて検

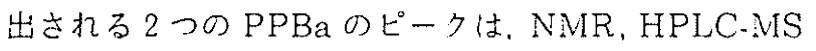
分折の結果，互いにエピマーで忍ることがわかっだ。得 ら狆たPPBa の吸取極大は408扩上じ667nmで，分子吸 光䋆数は51,900であった。な去，溶液中での安定性は， ベンジルアルコール, ポリソルベート20.ポリオキシエ チレン硬化ヒマシ油50が良好で㐫った。 


\section{一般演题 $1-1$}

担癌ヌードマウスにおける内視鏡的

$\mathrm{Nd}$ : YAG laser 局所温熱療法

(Endoscopic Laser-thermia)の

基礎的検討

\section{鳴海 裕之, 青木 純}

鈴木 荘太郎, 三輪 剛

東海大学医学部内科 6

\section{上山義人}

同病理

ヌードマウスに移植したヒト胃癌株(高分化型腺癌，中 分化型腺癌，低分化型腺癌) を対象として Laserthermia (以下LT)単独に上る組織学的所見を唡討した。 $2 \mathrm{~W}$ ， 0.1 秒 pulse 照射， $42 \sim 43^{\circ} \mathrm{C}$ ，10分間の条件でLT在施 行し, 経時的に比較検討した。各腫薜株共にLT後に著 明な壊死層が形成されたが、組織型間に明らかな量的な 相遠は認ら机なかった。照射7日後の高分化型腺癌，中 分化型腺䆛において壊死周囲に肉芽組織の增生か影著一゙ あり，1カ月後ではより著明であった。一方、低分化型 腺磨では照射 7 日後に打いて同部位に肉茅組織は認的的

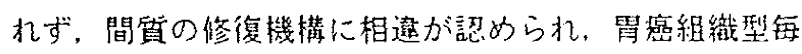
にLT効果が異なることが示唆された。

\section{一般演題 $1-2$}

バルーンレーザー温熱療法に打ける 治療条件の検討

竹内 信良"，西福 幸二，二ツ木浩一， 山本 邦男，神日 裕三，上原 解敬" ， 関口芳男 ${ }^{31}$

埼玉県立がんセンター 消化器科", 病理部 (研究所)" , SLT/Japan Co.LTD"
いて检討を重ねた結果、より低いレーザー出力で治候可 能なシステムが必要であると思狆机た。ここで，搪散し たレーザー光を照射でをるクオーツファイバー（搪散型

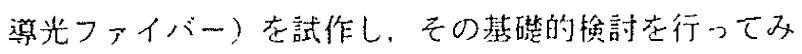
たが、期待されたほどの低出力化は迸成できなかった。 この原因として，レーザー光の減衰摔が大きく，先端出 力が非常に低くなっていることが判明した。今後、減塏

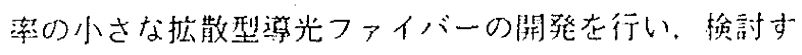
る予定である。

\section{一般演題 $1-3$}

レーザーサーミアに関する臨床的砄究

間宮均人, 杉原真, 篠田 昌孝,

笹野陽子、陳建彰、恒川洋

名鉄病院消化器科

伊奈 研次、森瀬 公友

名古屋大学第一内科

渡辺 喜則, 恒川力

名古屋レーザー医学研究所

早期蜀癌に対する内視鏡的レーザ一温熱療法の治療成

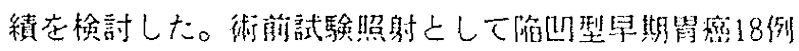
中 4 例で虚紧部の完全消失を認的。12例ではレーザー溃 揚低部に䖒の遗残はなく、本治療法の胃壁深部への照射 効果が明らかとなった。照射後のレーザー溃湟はU1ー2 以下の浅い溃㿑ですり，陷凹型癌に対する本治療法の安 全性も証明された。次に乎街不能1例，手街拒货2倒に 対して本治療法による局所根治治療奆行った。13例中1

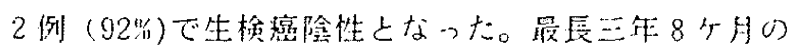
症例夻含む11例で矿所再発抄よび遠隔転移在認めていな

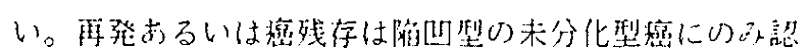

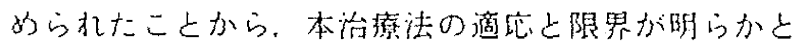
なった。

我々は，前回報告したバルーンレーザー温熱療法につ 
一般演題 $1-4$

胆道癌に対する接触型レーザー治療

篠田昌孝, 杉原真, 間宫 均人, 笹野陽子、陳建彰、恒川洋

名鉄病院消化器科

伊奈 研次, 森瀨 公友

名古屋大学第一内科

渡辺 喜則, 恒川力

名古屋レーザー医学研究所

我々は内瘘困難な胆管癌に対し PTCS 下に接触型 レーザー治療を試み良好な成績を得た。症例1は81才男 住. 黄㾝を主培として来院。上部胆管癌亡診断し PTC Sミにラウンドチップ型プローブを用い20W1秒の接触 レーザー照射在くり返し内瘦化。症例 2 は62才男性, 黄 疸にて近医上り紹介入院。下部胆管癌之診断し PTCS 下に高搪散ロッド型プローブを用い2W15秒の照射条件 でレーザーサーミア施行し内糜化。病理組䋨所見で十二 指揚表層に残存した腺癌の像を認むがレーザーサーミア 施行の下部胆管癌に癌の残存老認めず。胆道癌において 低出カのレーザーサーミアでは内種化による quarity of lifeの问上が上り女全確奏に得ら机，锋学的治療の一 環上しても局所根治の可能性在有すると考えら执た。

\section{一般演題 2-1}

口腔領域におけるレーザーサーミア，

1. 家兔正常舌に対する基礎的検討

\author{
渡辺 喜則, 恒川力 \\ 名古屋レーザー医学研究所 \\ 豊田哲郎 \\ 黄知県済生会病院蒾科口腔外科
}

伊藤 振本, 奥村 秀則, 竹内来 名鉄病院继科

龟山 洋一郎

愛知学院大学病理

河合幹

雾知学院大学第 2 口腔外科

恒川洋

名鉄病院消化器科

舌正常組織に対し，同じレーザー発生機器から一方に はサフォイア䌘プローブによる影腤を。また他方には レーザーによってサファイア䌘と同型のステンレス製の プローブを加温させることにより，熱を光の相加効果 (レーザーサーミア) と熱のみの効果い八イパーサーミ ア)とし，各々の経日的变化在肉眼的，病理学的に挨討 した。その結果、熱の敃のハイパーサーミアは、舌の上 皮老特に加温し、深部へ行く程影隌は少ない。レーザー サーミアでは上皮はハイパーサーミアより影㮣は少ない が深部は筋肉線維間陌の应大、配列不正さらに梱胞浸潤 も著明でこの影響は大きい。 


\section{一般演题 2-2}

口腔領域におけるレーザーサーミア,

2 . 家兔舌腫瘍に対する基礎的検討

渡辺喜則，恒川力

名古屋レーザー医学研究所

豊田 哲郎

带知県済生会病院蒾科口腔外科

亀山 洋一郎

萦知学院大学病理

河合幹

䁙知学院大学第 2 口望外科

恒川 洋

名鉄病院消化器科

䐊、体重 $2 \mathrm{~kg}$ の家鬼舌側緑にVX-2 株を移植し、直 径 $5 \mathrm{~mm}$ 程度に增殖した時点でレーザーサーミア $42^{\circ} \mathrm{C}$

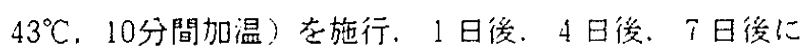
おける肉眼的, 組織学的变化を觀察した。施行 1 日後か ら腫癔のプローブ刺入部位より、腫㾨細胞の填死像が認 められた。またさらに4 日後.7日後を経て腫㾤細胞の 壊死像か增大し，炎症細胞の水腫も認的机た。上上の ことは，単なる熱勃果だけでなくレーザー光の光と熱の 効果が，正常組織と同様以上に関倸し，その殺細胞効果 があること走惨した。

\section{一般演題 $2-3$}

口腔外科領域レーザーサーミア臨床

の条件設定に関する研究

小野敬一郎，松島りん太郎，水城 春美 大分医科大学速科口腔外科学講座

口腔外科領域レーザーサーミアに执ける条件設定の基 礎的研究索始如に当たり，家象正常舌に於ける肉眼的，
組織学的变化の検索を予俑奏験として行ったので，その 概要を報告した。 Laserthermia 照射条件は $5 \mathrm{~W}$ ，40分。 43-44 $\mathrm{C}$ の条件で，家鬼の正常舌背中央部老用いた。照 射直後では浮腫が著明ですったが，細胞自体の变性は! とんど認めず，やや暒机て変化が起こった。組織の変性 ・壊死は 3 日目がもっとも強く.1週目. 2 週目之組織 修復が盛んですった。 laser probeの微妙な刺入方向の 違いによっては，变性、壊死組織の形態か中央から舌緑 に延びた槥状在呈し、左右非対称之なった。条件設定上

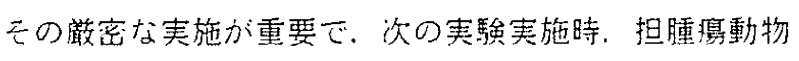
の採用之共に必須の娭討課題ですると考えら机る。

\section{一般演題 2-4}

Argon laser angioplasty に関する 基礎的, 臨床的研究

吉田 正人, 岡田 昌義, 辻 義彦, 中村 和夫

$$
\text { 神戸大学第二.外科 }
$$

我々は, Bare ended probe (以下BEP) と Metal tip probe (以下MTP)の 2 理頪の laser probeを用い $\tau$ Argon laser angioplasty の研究在行い. 各 probe に㧍ける至適なるlaser照射条件抽よび照射方法につい て娭討を加えた結果，BEPでは血管内視鏡を用いて直 視下にlaser 照射するのが安全であり，一方，MTPで は tip 先端部の温度变化が laser 照射の病变に対する効 果に大きな影響を与えることを確認し、价の大きさに 応じて至適な tip 温度蓒囲内になる上うに一回照射の条 件を可变し、さらに血管经に適台した probe 在選択す ることが重要でらつた。こ机らの基䃂的研究老もとに， 現在までに16例の慢性下肢動脈閉塞症に対して。臨床応 用在行ってきたが，その成績㧍上び治療上の問題点につ いてもすわせて報告する。 
一般演題 $2-5$

Nd：YAG Laser 焼灼術を施行した 気管支内過誤腫の一例

下元 博史、今泉 和良，溝口 健二 名鉄病院呼吸器科

恒川洋

名鉄病院消化器科

池田 拓也

名古屋大学第一内科

症洌は68 才女性。昭和 63 年 3 月に愘血を主訴に来院。

入院持娭査所見で胸部 $X$ 線写真上，左下肺野に一部粒状 陰影があり，軽度の低酸素血症を認めた。気管支鏡娭査 では，左気管支には異常を認めず，右中間幹に正常粘膜 に被浸された表面は平滑で弾性硬。境界明睹な直径 $5 \mathrm{~mm}$ の隆艳性病变を認めた。同部位の生娭で軟骨組織からな る気管支内軟骨腫之思吅机，Nd：YAG Laser 焼灼術 を施汀した。しかし焼灼術㣪，照射部位からの生検にて 軟骨生過䛊腫之彭断した。術後腫留は縮小しており1年 経過湲も增大していない。Nd：YAG Laser 焼灼術は こ机までの外科療法にかわる有用治療法之思わ机る。 